\title{
QUALITY PARAMETERS OF HORIZONTALLY SPRAY-DRIED FERMENTED CABBAGE JUICE
}

\author{
Liene Jansone", Solvita Kampuse, Zanda Krūma, and Ivo Līdums \\ Faculty of Food Technology, Latvia University of Life Sciences and Technologies, 22 Rīgas Str., Jelgava, LV-3004, LATVIA \\ \# Coresponding author, liene.jansone@gmail.com
}

Communicated by Sandra Muižniece-Brasava

\begin{abstract}
In the production of fermented cabbage, cell juice of cabbage is released, which is highly saturated in biologically active compounds, but is considered as a by-product. The aim of this study was to evaluate the quality parameters of dehydrated fermented cabbage juice using maltodextrin as a coating agent at various concentrations. In this experiment, fermented cabbage juice was used - spray dried on a horizontal spray-dryer and maltodextrin, in different concentrations ( 0 ; 5; $10 \%)$. Physical (water activity, solubility, salt content, and moisture), chemical (total phenolic concentration, antiradical activity, and organic and titratable acid concentration) and microbiological (total plate count and lactic acid bacteria) analyses were carried out. The major acids identified were oxalic, quinic, lactic, and acetic acid. Total phenol concentration was influenced by the concentration of maltodextrin used with higher values in the samples with no coating agent. The total viability of microorganisms and lactic acid bacteria $\left(8.9 \cdot 10^{3}-4.2 \cdot 10^{4}\right.$ colony forming units $(C F U) \cdot g^{-1}$ ) did not reach the probiotic potential according to FAO and WHO. Salt concentration ranged from $8.9 \%$ to $14.3 \%$, moisture content was $5.3 \%$ to $7.03 \%$, solubility in water $-81.74 \%$ to $82.8 \%$. Horizontal spray drying with maltodextrin as a coating agent proved to be a suitable solution to obtain an innovative product - dehydrated fermented cabbage juice.
\end{abstract}

Keywords: sauerkraut juice, dehydrated juice, maltodextrin concentrations.

\section{INTRODUCTION}

White cabbage (Brassica oleraceae var. capitata f. alba) is a well-known vegetable that is grown worldwide (Šamec et al., 2017) for culinary and medical purposes (Šamec and Salopek-Sondi, 2019). It can be stored raw or fermented as sauerkraut (Šamec et al., 2017). White cabbage leaves are shredded and due to osmotic pressure created by $\mathrm{NaCl}$ addition, the cell juice of cabbage is released and fermentation is induced by lactic acid bacteria, present in the raw material. It is highly saturated with biologically active compounds (Raak et al., 2014). In manufacture of fermented cabbage, the cell juice or fermented cabbage juice is considered as a by-product or residue, and can amount to $30 \%$ of initial cabbage weight. However, this residue can be used as a valuable source of various bioactive compounds (Beganović et al., 2014). Innovative and sustainable solutions are being explored for utilisation of this worthy by-product. Dried vegetable and fruit powders are convenient for consumption, easy to handle and have a longer shelf life (Pang et al., 2014). They have wide application in the food industry, supplementing the end product with bionutrients, colour, taste, fibre etc. Various drying techniques are used to make vegetables and their by-products into powder form to stop microbiological activity and preserve the product and its bioactive compounds. The applied drying system has a key role in determining final moisture content, hygroscopicity, quality and shelf life of the obtained product (Salehi and Aghajanzadeh, 2020). Spray drying is recognised for its low cost, high reproducibility and applicability to thermo-labile materials, due to the short drying time (Barbosa and Teixeira, 2017). The liquid substance is sprayed by an atomising device to create small droplets that are "shocked" with hot air, resulting in moisture evaporation and formation of dry solid particles that are separated from the hot air flow in a cyclone (Gharsallaoui et al., 2007). Spray drying is often used in the food industry to ensure the microbiological stability of the product, reducing biological degradation, transport cost and storage (Avila et al., 2015). Drying itself may not be a difficult task, but the choice of a coating agent may be challenging. The function of the coating agent is primarily to reduce stickiness by raising the glass transi- 
tion temperature of the substance, but the selection and concentration of the coating agent also influence the powder properties (Barbosa and Teixeira, 2017), and is crucial for the viability of microorganisms during spray drying and storage (Teijeiro et al., 2018). Coating agents with high molecular weight are commonly used for this purpose to equalise substance with low molecular weight that cannot be dried alone in their pure state. Previous studies, perfomed with malt drink, proved to be effective using maltodextrin as coating agent and spray-drying horizontally (Lidums et al., 2016). Maltodextrin is one of the most common used coating agents, because it increases $T_{g}$ of the sugar and acid rich products that are heat sensitive, and since it has good solubility and low hygroscopicity (Suhag et al., 2018). It is easy to use in the industry and has no taste or aroma (Avila et al., 2015). Findings from encapsulating Orthosiphon stamineus extract and honey powder (Suhag et al., 2018) show better preserved polyphenol compounds and (Pang et al., 2014) probiotic viability using maltodextrin (Medeiros et al., 2014). For every individual product, there is a need to determine the optimum coating agent or combination of several, as well as their concentration, in order to eliminate degradation of bioactive compounds and enhance physical properties (Shishir and Chen, 2017).

The aim of this study was to evaluate the quality parameters of dehydrated fermented cabbage juice using maltodextrin as a coating agent at various concentrations.

\section{MATERIALS AND METHODS}

The experimental study was carried out at the Latvia University of Life Sciences and Technologies, Faculty of Food Technology, but spray drying was carried out in Tecoma Drying Technology SRL, Italy.

Spray-drying. Fermented cabbage juice from a cabbage production plant "Dimdini," was collected after producing sauerkraut by a classic technology used in the fermentation, and delivered to Tecoma Drying Technology SRL, in a 200 1 barrel. It was spray dried in a horizontal spray dryer Gatedryer Turbo 150 GGI FB PT with an expected hourly input of $\pm 15 \mathrm{~kg} \cdot \mathrm{h}^{-1}$ inlet/outlet temperature $160 / 75^{\circ} \mathrm{C}$, and expected evaporation capacity $135 \mathrm{~kg} \cdot \mathrm{h}^{-1}$. Different maltodextrin concentrations $(0,5$, and $10 \%)$ were used. The samples were labelled as follows: 1MD10 - 10\%, 2MD10 $10 \%, 3 \mathrm{MD} 5-5 \%$; and $4 \mathrm{MD} 0-0 \%$ maltodextrin. $5 \mathrm{~g} \cdot \mathrm{l}^{-1}$ $\mathrm{CaCO}_{3}$ was added to neutralise $\mathrm{pH}$ (except 2MD10$\left.3 \mathrm{~g} \cdot \mathrm{l}^{-1}\right)$.

After spray-drying, the samples were kept in sealed plastic containers, in the dark at $22 \pm 1{ }^{\circ} \mathrm{C}$ temperature.

Physical, chemical and microbial analysis. Water activity $\left(\mathrm{a}_{\mathrm{w}}\right)$ was determined using an Aw meter Labswift. Three replications were made for all samples.

Solubility of dehydrated fermented cabbage juice was determined as described previously by Kuck and Noreńa (2016): $1 \mathrm{~g}$ of dehydrated fermented cabbage juice was mixed with
$30 \mathrm{ml}$ of deionised water and stirred for $30 \mathrm{~min}$. The solution was transferred to a centrifuge tube and centrifuged at $3500 \mathrm{rpm}$ for 6 minutes. Then $20 \mathrm{ml}$ of centrifuged solution was transferred into a pre-weighed sand dish and dried at $105{ }^{\circ} \mathrm{C}$ to constant weight. The solubility was calculated as follows:

Solubility $(\%)=\frac{\text { initial weight }- \text { final weight }}{\text { initial weight }} \times 100$

Moisture content was determined by calculating the weight loss after heating samples at $105{ }^{\circ} \mathrm{C}$ to a constant weight, according to standard ISO 1666:1996 and expressed on a dry basis.

Salt concentration was determined by titration using Mohr's method (ISO9297:1989) for determination of chloride, and expressed as sodium chloride. Silver nitrate solution and potassium chromate indicator were used (Korkmaz, 2001.

For determination of titratable acid concentration, $1 \mathrm{~g}$ of dehydrated fermented cabbage juice was measured in a $25 \mathrm{ml}$ conic flask. $100 \mathrm{ml}$ deionised water at $90{ }^{\circ} \mathrm{C}$ was added and the solution was stirred. Three drops of phenolphthalein were added and the solution was titrated with $0.1 \mathrm{n} \mathrm{NaOH}$, till a pink colour occurred. The results were expressed as $\mathrm{g} \cdot 100 \mathrm{~g}^{-1}$.

The organic acid profile was determined (Tomsone et al., 2020), using a high performance liquid chromatograph Shimadzu LC-20 Prominence, equipped with a pump system and UV/Vis detector (DAD SPD-M20A), gradients: AAcetonnitrile; $\mathrm{B}-0.05 \mathrm{M} \mathrm{KH} \mathrm{KO}_{4}$ monitored at $210 \mathrm{~nm}$, column Alltech $\mathrm{C} 18(4.6 \mathrm{~mm} \times 250 \mathrm{~mm})$, flow rate 1.25 $\mathrm{ml} \cdot \mathrm{min}^{-1}$, and temperature $35^{\circ} \mathrm{C}$.

Extracts for determination of total phenol concentration and antiradical activity (DPPH; $\mathrm{ABTS}^{+}$) were obtained by two methods based on water and acidified ethanol extractions (Gouw et al., 2017), with modifications.

For the preparation of water extracts, samples of fermented cabbage juice $(10 \mathrm{~g})$ and dehydrated fermented cabbage juice $(1 \mathrm{~g})$ were extracted with $20 \mathrm{ml}$ deionised water by stirring on a magnetic stirrer for $2 \mathrm{~h}$, then stored at $4 \pm 2{ }^{\circ} \mathrm{C}$ till further analyses.

For the preparation of acidified ethanol extracts, dehydrated fermented cabbage juice $(2 \mathrm{~g})$ was extracted with $30 \mathrm{ml}$ of $60 \%$ ethanol acidified with $1 \%$ acetic acid glacial in an ultrasonic water bath for $20 \mathrm{~min}$, and then centrifuged for three minutes at 3500 rounds per minute

Total phenol concentration (TPC) was determined using Folin-Ciocalteu reagent, according to Singleton et al. (1999), with some modifications. $0.5 \mathrm{ml}$ sample extract was mixed with $2.5 \mathrm{ml}$ Folin-Ciocalteu reagent (diluted ten times with deionised water) and left to react for five minutes. Then $2 \mathrm{ml} \mathrm{7.5 \%} \mathrm{Na}_{2} \mathrm{CO}_{3}$ was added and left to react for another 30 minutes. The absorption was read spectrophotometrically at $765 \mathrm{~nm}$ wavelength on a JENWAY 6300 (Baroworld Scientific Ltd., UK). 
Table 1. Physical and chemical characteristics of dehydrated fermented cabbage juice

\begin{tabular}{c|c|c|c|c}
\hline Sample & $\begin{array}{c}\mathrm{NaCl}, \\
\mathrm{g} \cdot 100 \mathrm{~g}^{-1}\end{array}$ & Moisture, $\%$ & Water activity, $\mathrm{a}_{\mathrm{w}}$ & $\begin{array}{c}\text { Solubility in water } \% \\
\mathrm{~g} \cdot 100 \mathrm{~g}-1\end{array}$ \\
\hline 1MD10 & $8.70 \pm 0.34 \mathrm{c}$ & $5.08 \pm 0.28 \mathrm{~b}$ & $0.210 \pm 0.005 \mathrm{a}$ & $81.74 \pm 0.66 \mathrm{a}$ \\
2MD10 & $8.93 \pm 0.07 \mathrm{c}$ & $5.30 \pm 0.23 \mathrm{~b}$ & $0.191 \pm 0.004 \mathrm{~b}$ & $82.76 \pm 0.82 \mathrm{a}$ \\
3MD5 & $12.23 \pm 0.18 \mathrm{~b}$ & $7.04 \pm 0.02 \mathrm{a}$ & $0.198 \pm 0.004 \mathrm{~b}$ & $82.80 \pm 0.21 \mathrm{a}$ \\
4MD0 & $14.31 \pm 0.07 \mathrm{a}$ & $7.03 \pm 0.14 \mathrm{a}$ & $0.183 \pm 0.004 \mathrm{~b}$ & $82.57 \pm 0.54 \mathrm{a}$
\end{tabular}

Values with different letters are significantly different $(p<0.05)$.

To obtain a stock solution for $\mathrm{ABTS}^{+}$decolouration, potassium sulphate as the oxidant agent was added and left to react for $12 \mathrm{~h}$ in the dark. To prepare a working solution, phosphate buffered saline (PBS) was added to the stock solution to reach an absorption of $0.800 \pm 0.030$ at $734 \mathrm{~nm}$. $0.05 \mathrm{ml}$ sample extracts were added to $5 \mathrm{ml}$ working solution and left to react for 10 minutes. Three replications were made for determination of $\mathrm{ABTS}^{+}$antioxidant activity using spectrophotometry, as described by Rokaya (2013) with some modifications.

To obtain freshly made stock solution for DPPH, $0.004 \mathrm{~g}$ of agent were mixed with $96 \%$ ethanol to reach an absorption of $1.000 \pm 0.02$ at $517 \mathrm{~nm} .0 .5 \mathrm{ml}$ sample extract was added to $3.5 \mathrm{ml}$ of stock solution and left to react in the dark for $30 \mathrm{~min}$, as described by Thapong with some modifications. The analyses were done in three replications and the DPPH antioxidant activity was determined spectrophotometrically.

For microbial analyses $10 \mathrm{~g}$ of dehydrated fermented cabbage juice and $10 \mathrm{~g}$ of fermented cabbage juice were diluted in $90 \mathrm{ml}$ sterile saline $(85 \% \mathrm{NaCl})$ and homogenised with a stomacher (Bagmixer Interscience, Bois Arpents F.) for 1 min at 8 strokes per second using internal filter bags. A 1 $\mathrm{ml}$ and $0.1 \mathrm{ml}$ of filtrate was plated on petri dishes. Scharlau brand selective media were used, all sterilised in an autoclave. For total plate counts, agar PCA (Ref.no. 01-161500) was used, and for lactic acid bacteria - MRS agar (ref.nr. 01-135-500. The samples were incubated as follows: PCA $30{ }^{\circ} \mathrm{C} 48 \mathrm{~h}$; MRS $37{ }^{\circ} \mathrm{C} 72 \mathrm{~h}$. Enumeration was carried out on an Acolyte colony counter.

Statistical analyses. Data were analysed using one factor analyses of variance (ANOVA), significant differences between the means were determined by Duncan's multiple range test. Pearson correlation coefficients were calculated using Excel software (Microsoft).

\section{RESULTS}

The composition of fermented cabbage juice was as follows: dry matter $8 \%, \mathrm{pH} 2.66, \mathrm{NaCl} 1.24 \%$, titratable acid $0.33 \mathrm{~g} \cdot 100 \mathrm{~g}^{-1}$ and ascorbic acid $52 \mathrm{mg} \cdot 100 \mathrm{~g}^{-1}$, and total phenol concentration $743.51 \mathrm{mg} \cdot 100 \mathrm{~g}^{-1}$. The lactic acid bacteria count in fermented cabbage juice was $14 \cdot 10^{4}$ CFU.g ${ }^{-1}$. Physical and chemical characteristics of dehydrated fermented cabbage juice are presented in Table 1. The dehydrated fermented cabbage juice sample with no MD (4MD0) added had the highest salt (14.31 $\pm 0.07 \mathrm{~g} \cdot 100$ $\left.\mathrm{g}^{-1}\right)$ and titratable acid concentration $(0.44 \pm 0.13 \mathrm{~g} \cdot 100$ $\mathrm{g}^{-1}$ ). Moisture content ranged from $5.3 \pm 0.23 \%$ in sample $2 \mathrm{MD} 10$ to $7.04 \pm 0.02 \%$ in sample $3 \mathrm{MD} 5$. Water activity was the highest in sample $1 \mathrm{MD} 10\left(\mathrm{a}_{\mathrm{w}}=0.21\right)$ and the lowest in sample 4MD0 $\left(\mathrm{a}_{\mathrm{w}}=0.183\right)$. Solubility in water ranged from $81.74 \pm 0.66 \%$ in sample $1 \mathrm{MD} 10$ to $82.8 \pm$ $0.21 \%$ in sample $3 \mathrm{MD} 5$.

Organic acid profile. In total, six organic acids were identified in fermented cabbage juice and in dehydrated fermented cabbage juice (Fig. 1). Mallic and ascorbic acids were present in relatively lower amounts in dehydrated fermented cabbage juice, ranging 0.19-0.44 g.100 g $\mathrm{g}^{-1}$ malic acid to $0.02-0.07 \mathrm{~g} \cdot 100 \mathrm{~g}^{-1}$ ascorbic acid. There was an effect of MD on relative breakdown of organic acids. For, example oxalic acid concentration ranged from $12.4 \mathrm{~g} \cdot 100 \mathrm{~g}^{-1}$ in sample MD10 to $21.84 \mathrm{~g} \cdot 100 \mathrm{~g}^{-1}$ in sample MD0) and acetic acid concentration from $11.15 \mathrm{~g} \cdot 100 \mathrm{~g}^{-1}$ in sample MD10 to $16.5 \mathrm{~g} \cdot 100 \mathrm{~g}^{-1}$ in sample MD0.

Total phenol concentration and antiradical activity. Total phenol concentration and antiradical activity extraction results are shown in Figure 2.

In the samples with no MD added, the phenol concentration was $738 \pm 20 \mathrm{mg} \mathrm{GAE} \cdot 100 \mathrm{~g}^{-1}$ dry weight (dw) in water extracts and $870 \pm 66 \mathrm{mg} \mathrm{GAE} \cdot 100 \mathrm{~g}^{-1} \mathrm{dw}$ in acidified ethanol extracts. In the sample 2MD10 the total phenol concentration was $339 \pm 22 \mathrm{mg} \mathrm{GAE} \cdot 100 \mathrm{~g}^{-1}$ in water extracts and $355 \pm 20 \mathrm{mg}$ GAE $\cdot 100 \mathrm{~g}^{-1} \mathrm{dw}$ in acidified ethanol extracts.

Antiradical activity assessed by DPPH showed highest activity with no MD additive $-574 \pm 4 \mathrm{mg}$ TE. $100 \mathrm{~g}^{-1}$ water extraction and $577 \pm 52 \mathrm{mg} \mathrm{TE} \cdot 100 \mathrm{~g}^{-1} \mathrm{dw}$ acidified ethanol extraction, compared to MD $10 \%$ additive $387 \pm 28$

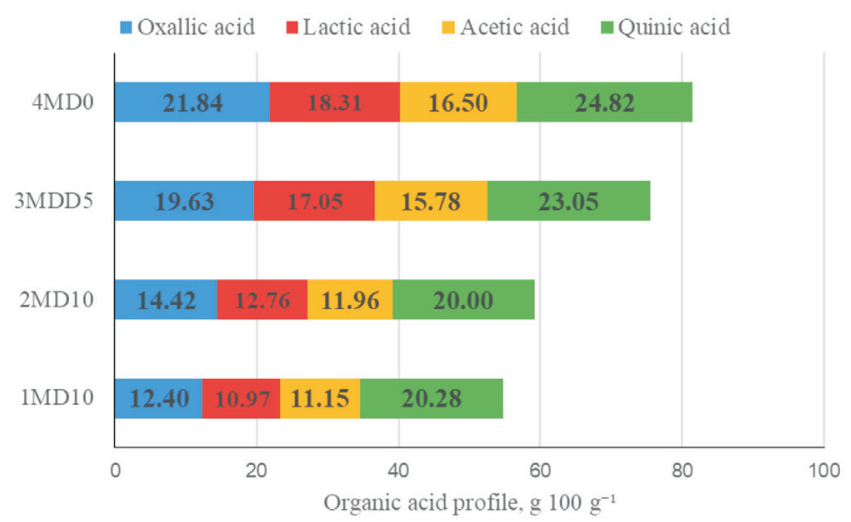

Fig. 1. Profile of four major organic acids in dehydrated fermented cabbage juice. 


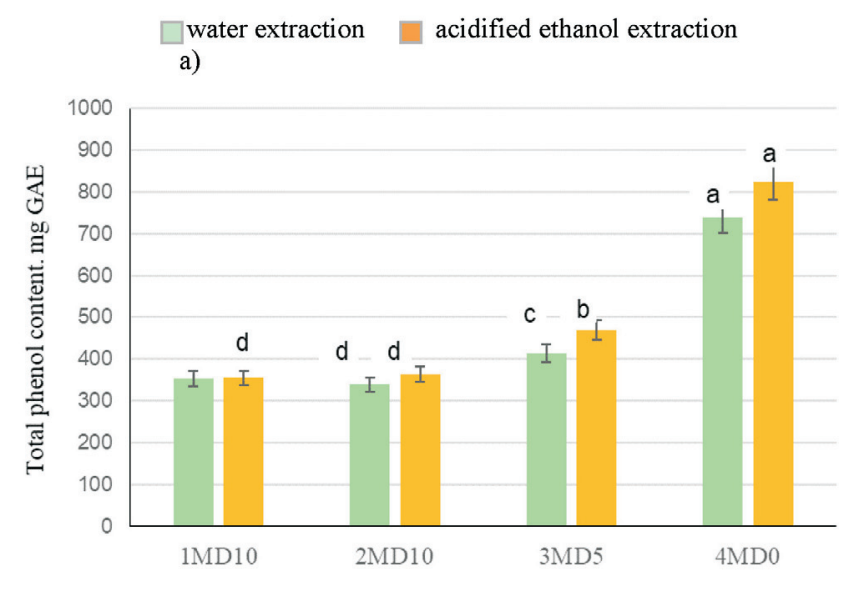

b)

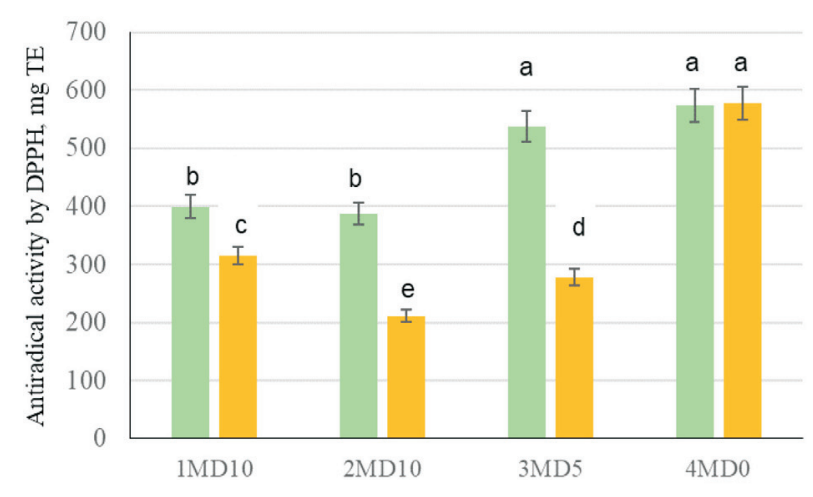

c)

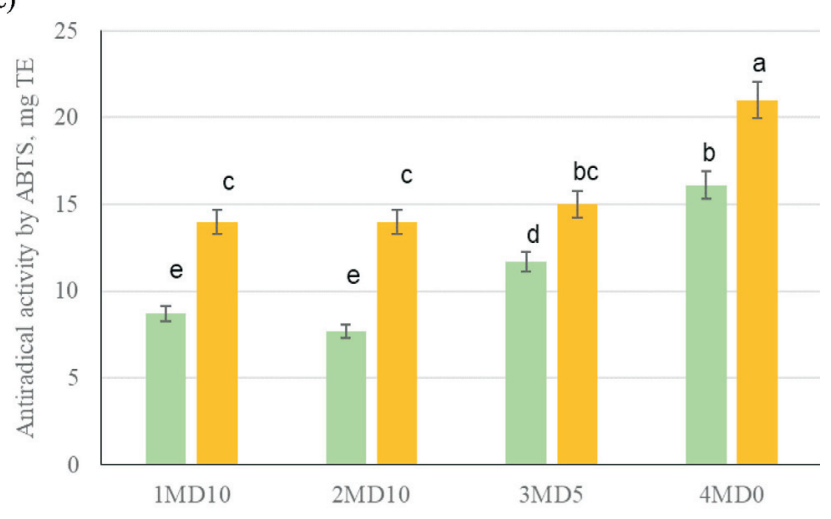

Fig. 2. Total phenol concentration (a) and antiradical activity (DPPH (b); $\mathrm{ABTS}^{+}(\mathrm{c})$ assay) extraction results, expressed as dry weight (dw), mg.100 $\mathrm{g}^{-1}$. Values with different letters are significantly different.

TE $100 \mathrm{~g}^{-1}$ and $211 \pm 50 \mathrm{mg}$ TE$\cdot 100 \mathrm{~g}^{-1} \mathrm{dw}$, respectively. ABTS was higher with acidified ethanol extraction and no MD additive.

Microbial parameters. Samples with $5 \%$ or $0 \%$ of MD additive showed higher lactic acid bacteria counts compared to samples with $10 \%$ MD additive, as shown in Figure 3.

\section{DISCUSSION}

In the analysed samples of dehydrated fermented cabbage juice (powder), $\mathrm{NaCl}$ concentration ranged from $8.7 \mathrm{~g} \cdot 100$

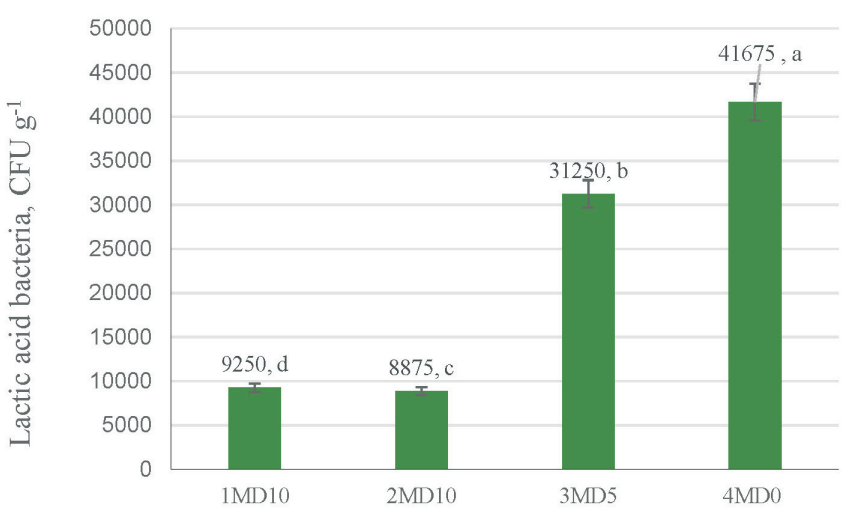

Fig. 3. Lactic acid bacteria in dehydrated fermented cabbage juice.

$\mathrm{g}^{-1}$ in samples with $10 \% \mathrm{MD}$ to $14.31 \mathrm{~g} \cdot 100 \mathrm{~g}^{-1}$ in samples with no coating agent (4MD0), which can be explained by the dilution of concentration. This $\mathrm{NaCl}$ concentration is considered to be as high, according to EU regulations (EU Science HUB, Health Promotion and Disease Prevention), and thus dehydrated fermented cabbage juice can be used in food formulations to replace salt. According to Latvian legislation (Regulation of Cabinet of Minister), the final content of additional salt in meat products is $1.25 \mathrm{~g}$ per $100 \mathrm{~g}$, and therefore the powder without coating agent could be added up to $9 \%$, if acceptable for other quality parameters.

For all the powder samples, water activity was sufficiently stable to inhibit development of microorganisms (below $0.77, \mathrm{FAO})$, but the parameters are influenced by the use of MD. Lower water activity occurred in the samples with no coating agent added.

The inverted results between water activity and moisture can be explained by the coating agent causing a change in the properties of powder (food components), like flowability, structure and surface activity, which determine water activity. Also, the oven drying method for determining moisture content may have caused a Maillard reaction producing water (Mathlouthi, 2001) in samples with less or no coating agent.

Solubility in water was characterised as good (high solubility considered 97\%) (Avila et al., 2015) and was $81.7-82.6 \%$ in the samples. No significant effect of MD influence was observed, and based on this parameter, the product was considered to be suitable for further use in food and cosmetic production. In comparison, the solubility of litchi juice powder was found to be 68.11 (Kalita et al., 2018).

There was slight effect of MD on titratable acid concentration, shown by a significant difference of MD0 from the other treatments.

The organic acid profile can be affected by many factors, such as the fermentation process, the state of raw material, types of microorganisms and many other (Shukla et al., 2010). Organic acids formed via metabolism of large mo- 
lecular mass compounds influence the taste and aroma of fermented products (Shukla et al., 2010). Oxalic and ascorbic acids are also naturally present in the raw cabbage, while other organic acids, such as lactic, acetic, formic and succinic acid are formed during fermentation (Drašković Berger et al., 2020). The intake of oxalic acid in European diets was estimated to be in the range of $5 \mathrm{mg}$ to $500 \mathrm{mg}$ per day, seasonally exceeding $1000 \mathrm{mg}$ per day, since it occurs in green leafy vegetable consumed during the growing season (EMEA, 2003). In our study, concentration of oxalic acid was 12.40 (MD10) to 21.84 (MD0) $\mathrm{g} \cdot 100 \mathrm{~g}^{-1}$.

In our study, total phenol concentration and antiradical activity were determined in water extract from dehydrated fermented cabbage juice, since the future applied use of the powder (meat; bread production) would be a dilution in water. Acidified ethanol extraction was used as in previous studies (Gouw et al., 2017) to assess the possibility of obtaining higher phenol concentration and antiradical activity. The results show a strong correlation between the methods $\left(\mathrm{r}=0.67\right.$ for DPPH, $\left.\mathrm{r}=0.93 \mathrm{ABTS}^{+} ; \mathrm{r}=0.97 \mathrm{TPC}\right)$, and total phenol concentration was also significantly correlated with antioxidant activity $(\mathrm{r}=0.83-0.89)$, which indicates that TPC reflects antioxidant activity.

Our study showed significant effect $(p<0.05)$ of maltodextrin on total phenol concentration using both extraction methods. In the samples with no MD added, the phenol content was $738 \pm 20 \mathrm{mg} \cdot 100 \mathrm{~g}^{-1} \mathrm{dw}$ in water extracts and 870 $\pm 66 \mathrm{mg} \mathrm{GAE} \cdot 100 \mathrm{~g}^{-1} \mathrm{dw}$ in acidified ethanol extracts. In sample MD10 the total phenol content was $339 \pm 22 \mathrm{mg}$ GAE $100 \mathrm{~g}^{-1}$ in water extracts and $355 \pm 20 \mathrm{mg}$ GAE 100 $\mathrm{g}^{-1} \mathrm{dw}$ in acidified ethanol extracts. It is not always the case that the coating agent will maintain the total phenolic concentration and free radical scavenging activity (Shishir and Chen, 2017) with higher concentration. Compared to several vegetable by-product powders (freeze dried and milled), total phenol concentration for white cabbage cutoffs was $341 \mathrm{mg} \mathrm{GAE} \cdot 100 \mathrm{~g}^{-1} \mathrm{dw}$, and for cauliflower cutoffs - $402 \mathrm{mg} \mathrm{GAE} \cdot 100 \mathrm{~g}^{-1} \mathrm{dw}$ (Wijngaard et al., 2009). In our study, samples of horizontally spray dried sauerkraut juice showed higher total phenol content.

Antiradical activity assessed by DPPH showed the highest activity with no MD (4MD0) addition $574 \pm 4 \mathrm{mg}$ TE$\cdot 100$ $\mathrm{g}^{-1} \mathrm{dw}$ in water extracts and $577 \pm 52 \mathrm{mg} \mathrm{TE} \cdot 100 \mathrm{~g}^{-1} \mathrm{dw}$ in acidified ethanol extracts, compared to samples with MD $10 \%$ addition: $387 \pm 28 \mathrm{TE} \cdot 100 \mathrm{~g}^{-1} \mathrm{dw}$ and $211 \pm 50 \mathrm{mg}$ $\mathrm{TE} \cdot 100 \mathrm{~g}^{-1} \mathrm{dw}$, respectively. For other vegetable powders, the DPPH activity was $284 \mathrm{mg} \mathrm{TE} \cdot 100 \mathrm{~g}^{-1} \mathrm{dw}$ for white cabbage cut-offs and $200 \mathrm{mg}$ TE. $100 \mathrm{~g}^{-1} \mathrm{dw}$ for cauliflower cut-offs (Wijngaard et al., 2009).

The stability of total phenolic concentration and antiradical activity is affected by the choice of the coating agent and spray drying technique. For the retention of heat sensitive compounds, the inlet and outlet temperature are of great importance (Fang and Bhandari, 2011). Previous studies (Kha et al., 2010; Fang and Bhandari, 2011; Krishnaiah et al., 2014) have suggested that the optimum parameters for spray-drying process to preserve TPC and antiradical activity is outlet temperature $120{ }^{\circ} \mathrm{C}$ and $10 \%$ (wet weight) maltodextrin. Increased MD concentration results in decrease of total antioxidant activity (Krishnaiah et al., 2014). Feed flow affects antioxidant compounds and moderate flow $\left(7.5 \mathrm{ml} \cdot \mathrm{min}^{-1}\right)$ can promote antioxidant activity (Romano et al., 2020). There is no large impact of time and storage temperature on TPC and antiradical activity for spray-dried non-juice and grains, but for bayberry powder (Fang and Bhandari, 2011) these factors are negatively associated with total phenolic retention rates.

In order to determine the benefits of spray-drying of fermented cabbage juice, we tested the viability of microorganisms in dehydrated fermented cabbage juice, in relation to addition of maltodextrin. According to FAO, WHO (2006) a functional food with a probiotic potential should reach at least $10^{7} \mathrm{CFU} \cdot \mathrm{g}^{-1}$. In our study, dehydrated fermented cabbage juice did not meet this standard. There was a major impact of maltodextrin in our samples on bacterial counts, with a range from $8.9 \cdot 10^{3}$ in MD10 to $4.2 \cdot 10^{4}$ in MD0 samples. Similar results were reported for kefir powder (Teijeiro et al., 2018).

A combination of effects influences the viability of microorganisms - heat, mechanical stress, pre- and post-processing, the use of coating agents, storage (Medeiros et al., 2014; Dianawati et al., 2016; Kalita et al., 2018; Teijeiro et al., 2018). Kalita et al. (2018) observed that cell viability decreased during storage using MD as a coating agent the survival of L. plantarum decreased significantly in lichi juice powder, compared to MD - pectin and MD - fructooligosacharide as coating agents. However, Medeiros et al. (2014) and Teijero et al. (2018) observed that survival of lactic acid bacteria (LAB) was better when spray-dried with a coating agent and maltodextrin had the best effect. This is in contrast with our study, where samples with $5 \%$ and $0 \%$ of MD addition show better survival of LAB. There was a strong (0.98) correlation between LAB and total plate count. Kalita et al. (2018) also observed that $\mathrm{pH}$ of around 4 had less severe effect on probiotic organisms than $\mathrm{pH}$ of 2. Teijero (2018) stated that for kefir powder the combination of whey permeate and maltodextrin and neutral $\mathrm{pH}$ (7) resulted in better lactic acid bacteria survival, and suggested that the acidic conditions during dehydration of kefir-derived lactobacilli was the main factor affecting their survival.

\section{CONCLUSIONS}

Production of dehydrated fermented cabbage juice is a new application of food waste and therefore quality evaluation is essential. The current experiments utilised horizontal spray-dryer with maltodextrin as a coating agent. There were many factors that influenced the outcome of fermented cabbage and its juice powder as the end product. Maltodextrin and its concentration played an important role in the drying process and the properties of the final product powder. 
Based on previous studies conducted with malt drink, which is physically similar to sauerkraut juice, spray drying was chosen as the most effective drying technology.

Our findings showed that dehydrated fermented cabbage juice is not a source of probiotics, although $\mathrm{NaCl}$ and organic acids in fermented cabbage juice may be a good salt and taste additive.

\section{ACKNOWLEDGEMENTS}

This study was supported by European Innovation Partnership for Agricultural Productivity and Sustainability Working Group Cooperation, project 18-00-A01612-000020.

\section{REFERENCES}

Adhikari, B., Howes, T., Bhandari, B. R., Truong, V. (2003). Characterization of the surface stickiness of fructose-maltodextrin solutions during drying. Drying Technol., 21 (1), 17-34.

Avila, E. L., Cortes Rodríguez, M., Ciro Velásquez, H. J. (2015). Influence of maltodextrin and spray drying process conditions on sugarcane juice powder quality. Rev. Fac. Nal. Agr. Medellín, 68 (1), 7509-7520.

Barbosa, J., Teixeira, P. (2017). Development of probiotic fruit juice powders by spray-drying: A review. Food Rev. Int., 33 (4), 335-358.

Beganović, J., Kos, B., Leboš Pavunc, A., Uroić, K., Jokić, M., Šušković, J. (2014). Traditionally produced sauerkraut as source of autochthonous functional starter cultures. Microbiol. Res., 169 (7-8), 623-632.

Dianawati, D., Mishra, V., Shah, N. P. (2016). Survival of microencapsulated probiotic bacteria after processing and during storage: A review. Crit. Rev. Food Sci. Nutr., 56 (10), 1685-1716.

Drašković Berger, M., Vakula, A., Tepić Horecki, A., Rakić, D., Pavlić, B., Malbaša, R., Vitas, J., Jerković, J., Šumić, Z. (2020). Cabbage (Brassica olerace $\mathrm{L}$. var. capitata) fermentation: Variation of bioactive compounds, sum of ranking differences and cluster analysis. LWT-Food Sci. Technol., 133, 110083

EMEA (2003). The European Agency for the Evaluation of Medicinal Products Veterinary Medicines and Inspections Committee for Veterinary Medicinal Products Oxalic Acid summary report.

https://www.ema.europa.eu/en/documents/ mrl-report/oxalicacid-summary-report-committee-veterinary-medicinal-products_en.pdf (accessed 17.12.2021)

Fang, Z., Bhandari, B. (2011). Effect of spray drying and storage on the stability of bayberry polyphenols. Food Chem., 129 (3), 1139-1147.

Gharsallaoui, A., Roudaut, G., Chambin, O., Voilley, A., Saurel, R. (2007). Applications of spray-drying in microencapsulation of food ingredients: An overview. Food Res. Int., 40 (9), 1107-1121.

Gouw, V. P., Jung, J., Zhao, Y. (2017). Functional properties, bioactive compounds, and in vitro gastrointestinal digestion study of dried fruit pomace powders as functional food ingredients. LWT - Food Sci. Technol., 80, 136-144.

Kalita, D., Saikia, S., Gautam, G., Mukhopadhyay, R., Mahanta, C. L. (2018). Characteristics of synbiotic spray dried powder of litchi juice with Lactobacillus plantarum and different carrier materials. LWT - Food Sci. Technol., 87, 351-360.

Kha, T. C., Nguyen, M. H., Roach, P. D. (2010). Effects of spray drying conditions on the physicochemical and antioxidant properties of the Gac (Momordica cochinchinensis) fruit aril powder. J. Food Eng., 98, 385-392.
Korkmaz, D. (2001). Precipitation titration: Determination of chloride by the Mohr method. Methods, 2 (4), 1-6.

https://pdf4pro.com/view/precipitation-titration-determination-of-chlorid e-by-the-527b72.html (accessed 16.12.2021).

Krishnaiah, D., Nithyanandam, R., Sarbatly, R. (2014). A critical review on the spray drying of fruit extract: Effect of additives on physicochemical properties. Crit. Rev. Food Sci. Nutr., 54 (4), 449-473.

Kuck, L. S., Noreña, C. P. Z. (2016). Microencapsulation of grape (Vitis labrusca var. Bordo) skin phenolic extract using gum Arabic, polydextrose, and partially hydrolyzed guar gum as encapsulating agents. Food Chem., 194, 569-576.

Medeiros, A., Thomazini, M., Urbano, A., Hoskin, R. T., Favaro-Trindade, C. (2014). Structural characterisation and cell viability of a spray dried probiotic yoghurt produced with goats' milk and Bifidobacterium animalis subsp. lactis (BI-07). Int. Dairy J., 39 (1), 71-77.

Lidums I., Karklina D., Kirse A. (2016) Characteristics of dry naturally fermented kvass obtained by spray drying. Res. Rural Devel., 22 (1), 106-110.

Mathlouthi, M. (2001). Water content, water activity, water structure and the stability of foodstuffs. Food Control, 12 (7), 409-417.

Pang, S. F., Yusoff, M. M., Gimbun, J. (2014). Assessment of phenolic compounds stability and retention during spray drying of Orthosiphon stamineus extracts. Food Hydrocolloids, 37, 159-165.

Raak, C., Ostermann, T., Boehm, K., Molsberger, F. (2014). Original research regular consumption of sauerkraut and its effect on human health: A bibliometric analysis. Global Adv. Health Med., 3 (6), 12-18.

Rokayya, S., Li, C. J., Zhao, Y., Li, Y., Sun, C. H. (2013). Cabbage (Brassica oleracea L. var. capitata) phytochemicals with antioxidant and anti-inflammatory potential. Asian Pacific J. Cancer Prev., 14 (11), 6657-6662.

Romano, N., Ureta, M. M., Guerrero-Sánchez, M., Gómez-Zavaglia, A. (2020). Nutritional and technological properties of a quinoa (Chenopodium quinoa Willd.) spray-dried powdered extract. Food Res. Int., 129, 108884.

Salehi, F., Aghajanzadeh, S. (2020). Effect of dried fruits and vegetables powder on cakes quality: A review. Trends Food Sci. Technol., 95, $162-172$.

Šamec, D., Pavlović, I., Salopek-Sondi, B. (2017). White cabbage (Brassica oleracea var. capitata f. alba): Botanical, phytochemical and pharmacological overview. Phytochem. Rev., 16 (1), 117-135.

Šamec, D., Salopek-Sondi, B. (2019). Cruciferous (Brassicaceae) vegetables. In: Nonvitamin and Nonmineral Nutritional Supplements. Academic Press, Amsterdam, pp. 195-202.

Shishir, M. R. I., Chen, W. (2017). Trends of spray drying: A critical review on drying of fruit and vegetable juices. Trends Food Sci. Technol., 65 , 49-67.

Shukla, S., Choi, T. B., Park, H. K., Kim, M., Lee, I. K., Kim, J. K. (2010). Determination of non-volatile and volatile organic acids in Korean traditional fermented soybean paste (Doenjang). Food Chem. Toxicol., 48 (8-9), 2005-2010.

Singleton, V. L., Orthofer, R., Lamuela-Raventós, R. M. (1999). Analysis of total phenols and other oxidation substrates and antioxidants by means of folin-ciocalteu reagent. Methods Enzymol., 299, 152-178.

Suhag, Y., Nayik, A., Nanda, V. (2018). Development of spray-dried honey powder with vitamin $\mathrm{C}$ and antioxidant properties using maltodextrin as a carrier. In: Innovative Food Science and Emerging Technologies. Chapter 25. Apple Academic Press, USA, pp. 596-607.

Teijeiro, M., Pérez, P. F., de Antoni, G. L., Golowczyc, M. A. (2018). Suitability of kefir powder production using spray drying. Food Res. Int., 112, 169-174.

Thaipong, K., Boonprakob, U., Crosby, K., Cisneros-Zevallos, L., Hawkins Byrne, D. (2006). Comparison of ABTS, DPPH, FRAP, and ORAC assays 
for estimating antioxidant activity from guava fruit extracts. J. Food Compos. Anal., 19 (6-7), 669-675.

Tomsone, L., Galoburda, R., Kruma, Z., Cinkmanis, I. (2020). Characterization of dried horseradish leaves pomace: Phenolic compounds profile and antioxidant capacity, content of organic acids, pigments and volatile compounds. Eur. Food Res. Technol., 246 (8), 1647-1660.

Wijngaard, H. H., Rößle, C., Brunton, N. (2009). A survey of Irish fruit and vegetable waste and by-products as a source of polyphenolic antioxidants. Food Chem., 116 (1), 202-207.

Received 22 March 2021

Accepted in the final form 14 January 2022

\section{HORIZONTĀLĀ TIPA IZSMIDZINĀŠANAS KALTĒ IEGŪTĀ SKĀBĒTU KĀPOSTU SULAS PULVERA KVALITATĪVIE} RĀDITTĀJI

Skābētu kāpostu pārstrādes procesā veidojas 30\% skābētu kāpostu sula, kas, tāpat kā skābēti kāposti, ir bagāta ar bioloğiski aktīviem savienojumiem. Pārfasēšanas un realizācijas rezultātā dạ̦a skābētu kāpostu sulas paliek neizmantota un tiek utilizēta kā atkritumprodukts. Meklējot risinājumus ilgtspējīgai un bezatlikumu tehnoloǵiju ieviešanai pārstrādes uzṇēmumos, kā viens no produktiem tiek pētīts dehidrēts skābētu kāpostu sulas pulveris. Šì pētījuma mērkis bija noskaidrot dehidrētas skābētu kāpostu sulas fizikālos (pH, mitruma saturs, ūdens aktivitāte, šķīīiba), ķīmiskos (titrējamās skābes, organisko skābju sastāvs, sāls saturs, kopējo fenolu daudzums un antiradikālā aktivitāte) un mikrobioloğiskos (pienskābes baktērijas) rādītājus. Pētījuma gaitā skābētu kāpostu sula tiek izsmidzināta horizontālā tipa izsmidzināšanas kaltē, kā nesējvielu izmantojot maltodekstīnu (MD) dažādās koncentrācijās $(0 ; 5 ; 10 \%)$. Mitruma saturs un ūdens aktivitāte ir atbilstoša, lai inhibētu mikroorganismus. Sāls saturs ir robežās no 8,9\% (paraugos ar 10\% MD) līdz 14,3 \% (0 \% MD), šķīdība ūdenī attiecīgi 82,8\% $81,74 \%$. Kopā tika identificētas sešas organiskās skābes — skābeņsķābe, hinskābe, pienskābe, etiḳskābe kā arī nelielos daudzumos askorbīnskābe un ābolskābe. Nesējvielas koncentrācija ietekmē kopējo fenolu un antiradikālo aktivitāti dehidratētā skābētu kāpostu sulā, labāki rezultāti ir paraugos ar $0 \%$ MD piedevu. Arī pienskābes baktēriju skaits mūsu pētījumā ir lielāks paraugos, kas kaltēti bez nesējvielas. 